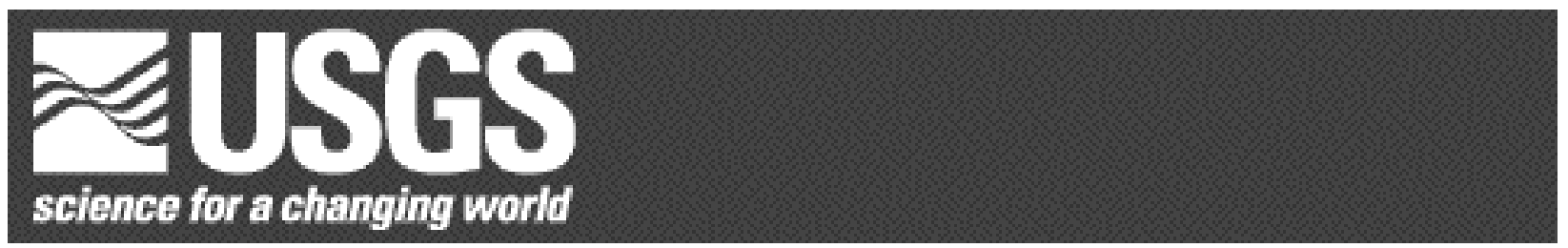

\title{
LOCATION AND AGE DATABASE FOR SELECTED FORAMINIFER SAMPLES COLLECTED BY EXXON PETROLEUM GEOLOGISTS IN CALIFORNIA
}

Compiled by Earl E. Brabb and John M. Parker 1

Open-File Report 03-429

2003

This report is preliminary and has not been reviewed for conformity with U.S. Geological Survey editorial standards or with the North American Stratigraphic Code. Any use of trade, firm, or product names is for descriptive purposes only and does not imply endorsement by the U.S. Government.

\section{U.S. DEPARTMENT OF THE INTERIOR}

U.S. GEOLOGICAL SURVEY

${ }^{1}$ Menlo Park, Calif. 


\section{INTRODUCTION AND BACKGROUND}

\subsection{Need for information}

Most of the geologic maps published for central California before 1960 were made without the benefit of age determinations from microfossils. The ages of Cretaceous and Tertiary rocks in the mostly poorly exposed and structurally complex sedimentary rocks represented in the Coast Ranges are critical in determining stratigraphic succession or lack of it, and in determining whether the juxtaposition of similar appearing but different age formations means a fault is present. Since the 1930's, at least, oil company geologists have used microfossils to assist them in geologic mapping and in determining the environments of deposition of the sediment containing the microfossils. This information has been so confidential that some companies even coded the names of foraminifers to prevent disclosure. In the past 20 years, however, the attitude of petroleum companies about this information has changed, and many of the formerly confidential materials and reports are now available. We report here on 1,964 Exxon foraminifer samples mostly from surface localities in the San Francisco Bay region, and elsewhere in California. Most but not all the samples were plotted on U. S. Geological Survey (USGS) 7.5' topographic maps or on obsolete USGS 15' maps. The information from the slides can be used to update geologic maps prepared without the benefit of microfossil data, to analyze the depth and temperature of ocean water covering parts of California during the Mesozoic and Cenozoic Eras, and for solving nomenclature and other scientific problems. A similar report on more than 30,000 slides for surface samples collected by Chevron geologists has been released (Brabb and Parker, 2003), and another report provides information on slides for more than 2000 oil test wells in Northern California (Brabb, Powell, and Brocher, 2001).

\section{PREPARATION OF THE DATA SET}

\subsection{Excel spreadsheet}

An Excel spreadsheet is provided for the data pertaining to foraminifers on a slide prepared for each locality. Each entry contains the name of the USGS topographic map where the foraminifers were collected; more specific information about where in a quadrangle the sample was found, the section, township and range, where available; miscellaneous information, such as whether or not the sample was obtained by an auger and whether or not an Exxon map was obtained to show the location of the sample; and the age of the fauna.

The initials of the collector, the numbers on aerial photographs, or the initials of a geographic locality were used on the foraminifer slides, on Exxon locality maps, and in paleontologic reports to identify samples. The following initials have been identified: BUU, photos in the Mt Diablo area; DAV, Davenport area; DB, Drakes Bay area; DLM, Dean Morgridge; DP, Del Puerto Creek area; EG, Empire Grade in the Felton area; HSS, Howard Sonneman; JC, Joseph Clark; JL, John Lively; JRS, John Switzer; JWS, John Smith; PA, Point Arena area; PR, Peter Rodda; RDO,

Robert Ottman; Shell, Shell Petroleum Company; RS, Rex Smith; SCC, Santa Cruz County; and WVJ, Wayne Jones. The following initials have not been identified: HR, ROS, JB, SAV, and TAH.

All slides along with copies of the locality maps and paleontologic reports have been given to the California Academy of Sciences.

\subsection{Paleontologic reports}

Paleontologic reports were provided for most of the Exxon surface samples. These reports provide the field number of the individual collector, the inferred age of the sample, and a list of the 
common and/or diagnostic foraminifers. None of the lists contain more than a dozen species, and most contain only a few. All age determinations are from foraminifers unless stated otherwise. The term "barren" refers only to foraminifers because most barren samples commonly contain other microfossils.

The ages of foraminifers generally follows the zonation of Goudkoff (1942) as modified by Almgren (1986) for the Late Cretaceous, and by Exxon paleontologists (unpublished reports) for the Early Cretaceous and Late Jurassic. The zones of the Eocene are mainly from Laiming (1940) as modified by Almgren and others (1986), except for the Narizian and Ynezian Stages which were defined by Mallory (1959). The Zones of the Oligocene and Miocene are generally from Schenck and Kleinpell ((1936) and Kleinpell (1938 and 1980).

\subsection{Age relationships with international standards}

Correlation of the Tertiary California benthic foraminifers with international standards has a long and controversial history that will not be repeated here, but some improvements can be made in ages assigned by Exxon paleontologists in the 1960's and earlier to bring them more in agreement with recent correlations. The boundaries of the Tertiary series are not generally controversial, although Poore (1980) and several others have pointed out that benthic foraminifers stages and zones are time transgressive and are different ages in different places. For purposes of this report, the following series and subseries boundaries will be used, following mainly the correlations of Almgren and others (1988), Kleinpell (1980), and Prothero (2001).

The base of the Eocene is at the base of the D zone of Laiming (1940), which rests on beds correlative with the E zone of Laiming (1940) and the Ynezian Stage of Mallory (1959), late Paleocene. The B-1, B-2, B-3, B-4, C, and D zones of Laiming (1940) are early Eocene, and the A-1, A-2, A-3, and B-1A zones of Laiming (1940) and the Narizian Stage of Mallory (1959) are arbitrarily middle Eocene in this report, although Poore and Brabb (1977) have pointed out that the boundary between the middle and late Eocene is within the A-1 zone. The Refugian Stage of Schenck and Kleinpell (1936) is considered late Eocene, and the entire Zemorrian Stage of Kleinpell (1938) is arbitrarily considered to be Oligocene. The early Miocene consists of the Saucesian and Relizian Stages of Kleinpell (1938). There is no convenient and widely accepted boundary between the middle and late Miocene, so in this report the Luisian Stage is middle Miocene, the Mohnian Stage is middle and late Miocene, and Delmontian Stages is late Miocene. The Delmontian Stage may extend into the Pliocene, but the top of the Delmontian Stage is arbitrarily considered the top of the California Miocene. Stages in the Pliocene and Pleistocene were not used by the Exxon paleontologists and are not used in this report.

\subsection{Card files}

Copies of 5- x 8-inch data cards were among the materials received from Exxon. Each card may provide information on where a sample was collected, who collected it, and the age of the sample as determined by an Exxon paleontologist. All this information is helpful in making a correlation between the foraminifer slide received, the locality map, and the paleontologic report. Unfortunately, these data cards were not provided for all of the samples, and many of the data cards lack specific locality and age information.

\section{EXPLANATION OF THE DATABASE}

The database is from an Excel spreadsheet with seven columns providing information mainly on the location and age of the foraminifers. The section, township and range for the sample is 
provided where known, but many samples do not have this information because USGS maps lack these data in areas of former Spanish ranchos, or because no Exxon locality maps were provided.

\section{USES OF THE EXXON DATA}

Exxon geologists used the age information from the foraminifer slides mainly to assist them in making geologic maps. One of these maps for the Mount Diablo area was released by the USGS with few changes and with the Exxon geologists as co-authors (Brabb, Sonneman, and Switzer, 1971). Other Exxon maps were used to compile a geologic map of Solano County and parts of Napa, Contra Costa, Marin, and Yolo Counties (Sims and others, 1973). More recently, the Exxon mapping has been recompiled with new geologic mapping and other data in digital geologic maps of Contra Costa and Alameda Counties, and the San Jose 1:100,000 quadrangle (Graymer, Jones and Brabb, 1994; Graymer, Jones, and Brabb, 1996; and Wentworth and others, 1999) and most of Solano County and parts of Napa, Contra Costa, and Yolo Counties (Graymer, Jones and Brabb, 2002).

\section{CONCLUSIONS}

This report contains nearly 2,000 paleontologic data points that have not previously been available to the public. The points will be useful in any recompilation of the geology to show the age of the various geologic formations and to indicate where additional and more complete microfossil faunas may be recovered.

\section{ACKNLOWLEDGEMENTS}

We are most grateful to the paleontologists, geologists, and managers with Exxon Petroleum Company who provided materials for this report. Larry Dickerson (deceased) helped to separate and arrange the slides. Louise Dickerson, Karen Wild, and Purty Dorn made preliminary inventories of the slides. Mary Bowen, Troy Douthit, Erica Drescher, Domenique Granier, William Malmborg, Sonoko Migitaka, Graeme Somerville, Orland Soave, William West, and Samantha Woodward also helped prepare slides for the database.

\section{REFERENCES}

Brabb, E. E., Sonneman, H. S., and Switzer, J. R., Jr., 1971, Preliminary geologic map of the MountDiablo-Byron area, Contra Costs, Alameda, and San Joaquin Counties, California: U. S. Geological Survey Open File Report, scale 1:62,500.

Brabb, E. E., Powell, Charles II, and Brocher, T. M., 2001, Preliminary compilation of data for selected oil test wells in Northern California: U. S. Geological Survey Open File Report 01-152, $310 \mathrm{p}$.

Goudkoff, O. S., 1945, Stratigraphic relations of the Upper Cretaceous in the Great Valley of California: American Association of Petroleum Geologists Bulletin v. 29, p. 956-1007.

Graymer, R. W., Jones, D. L., and Brabb, E. E., 1994, Preliminary geologic map emphasizing bedrock

formations in Contra Costa County, California: a digital database: U. S. Geological Survey Open-File

Report 94-622.

Graymer, R. W., Jones, D. L., and Brabb, E. E., 1996, Preliminary geologic map emphasizing bedrock formations in Alameda County, California: a digital database: U. S. Geological Survey Open-File Report 96-252.

Graymer, R. W., Jones, D. L., and Brabb, E. E., 2002, Geologic map and map database of the northeastern San Francisco Bay region: U. S. Geological Survey Miscellaneous Field Studies Map MF-2403.

Kleinpell, R. M., 1938, Miocene stratigraphy of California: Tulsa, OK, American Association of Petroleum Geologists, 450 p.

Kleinpell, R. M., 1980, The Miocene stratigraphy of California revisited: Tulsa, Oklahoma, American Association of Petroleum Geologists, Studies in Geology, p. 82-117. 
Laiming, Boris, 1940, Foraminiferal correlations in Eocene of San Joaquin Valley, California: American Association of Petroleum Geologists Bulletin v. 24, p. 1923-1939.

Poore, R. Z., and Brabb, E. E., 1977, Eocene and Oligocene planktonic Foraminifera from the upper Butano sandstone and type San Lorenzo Formation, Santa Cruz Mountains, California: Journal of Foraminiferal Research, v. 7, no. 4, p. 249-272.

Prothero, D. R., 2001, Chronostratigraphic calibration of the Pacific Coast Cenozoic: a summary in Prothero, D. R., ed., Magnetic stratigraphy of the Pascific Coast Cenozoic: Pacific Section SEPM, Book 91, p. 377-394.

Schenck, H. G., and Kleinpell, R. M., 1936, Refugian Stage of Pacific Coast Tertiary: American Association of Petroleum Geologists Bulletin, v. 20, p. 215-225.

Sims, J. D., Fox, K. F., Jr., Bartow, J. A., and Helly, E. J., 1973, Preliminary geologic map of Solano County and parts of Napa, Contra Costa, Marin, and Yolo Counties, California: U. S. Geological Survey Miscellaneous Field Studies Map MF-484, scale 1:62,00.

Wentworth C. M., Blake, M. C., Jr., McLaughlin, R. J., and Graymer, R. W., 1999, Preliminary geologic map of the San Jose 30 x 60 minute quadrangle, California: U. S. Geological Survey Open File Report 98-795. 